\title{
Development of Embroidered Bags Using Renewable Technology of Computer Embroidery Machines in Daboh Village, Aceh Besar
}

\author{
Mulia Saputra ${ }^{1}$, Muhammad Arfan ${ }^{2}$, Martunis $^{3}$ \\ $\{$ mulia_1@yahoo.com\} \\ ${ }^{1.2}$ Faculty of Economics and Business Syiah Kuala University, Banda Aceh \\ ${ }^{3}$ Faculty of Agriculture Syiah Kuala University, Banda Aceh
}

\begin{abstract}
The purpose of Community Service is to innovate products, in order to produce new products which usable by small and medium entrepreneurs to increase their income. Additionally, community service provides an alternative marketing path for effective and innovative packaging. The method applied in the community program is using an approach method that involves all members of the SME group actively which resulted in the beneficial program. The target of this activity is to develop a technology for making Aceh embroidery bags into suitcases and fabrics using Acehnese calligraphy. Thus, current production is only producing the backpacks, handbags, and sling bags. Therefore we need product innovation to increase the selling value of this Aceh embroidery bag. Moreover, these programs also desire to have a positive impact on increasing community income. The appropriate and efficient production system will support bag embroidery entrepreneurs to sustain and expand their business along with the increasing demand for these embroidery bags. The result of this community service was the formation of new products in the form of suitcases and mukena fabrics with various embroidery of Acehnese calligraphy. Then, another target is to the expansion of marketing and promotion in order to increase the income of the entrepreneurs.
\end{abstract}

Keywords: Embroidered bag, suitcase, fabric, Aceh calligraphy, embroidery machine

\section{Introduction}

Aceh has various kinds of embroidery products such as embroidered bags, Aceh Motif Embroidery Bags products are advanced products in terms of production and marketing. A wide variety of industrial products, Aceh Motif Embroidery Bags are well-known both nationally and internationally. The development of Aceh's motif embroidery art today has increased, considering its motif that has distinctive characteristics. Aceh Motif Embroidery Bag has its own charm considering the designs that are produced are diverse natural designs. This natural character means simple but has a high-quality motif.

However, the income capacity of these industrial craftsmen[1][2] is not enough to create welfare. It caused by limited business capital and lack of availability of raw materials for the manufacture of Aceh Motif Embroidery Bags. Acehnese motif embroidery business has developed in Dayah Daboh Village, Kec. Montasik, Aceh Besar since 1989. In the business process, it has experienced rise and fall, nowadays as the tourism of Aceh Province improves[3], especially following of the rehabilitation and reconstruction after the Tsunami 
and the peace of Aceh. Then, the Acehnese cultural handicraft industry is becoming stretching. Various bags, purses, and accessories with Acehnese motifs, Gayo Kerawang, and other creative motifs are easily found in Dayah Daboh Village, Kec. Montasik, Aceh Besar. Moreover, there is a person who is active in promoting handicraft household businesses in the Dayah Daboh Village, he is Mr. Marwan. Craftsmen use their home as a place of production as well as a display gallery of handicrafts[4][5].

\subsection{Current Conditions and Problems of Partners}

\section{a. Production Aspect}

1) To increase production capacity, there is sophisticated machines are needed, which are capable of producing in large quantities. These machines applied to fulfill large quantities of orders.

2) Another issue is when there is electricity off, it will hamper the production process because most of the machines use electricity.

3) Significant problems in this business are if there is an increase in the price of raw material, it will influence the increase in selling prices of Aceh Motif Embroidery Bags.

4) Lack of capital to increase production and having a lot of employees to produce Aceh embroidery bags.

\section{b. Management Aspect}

In term of management aspect of the business, the embroidery bag producers still face several issues, including:

1) Lack of ability of business practice in calculating production costs, which affected to inaccurate of the embroidery bags selling price.

2) In general, there are obstacles in international selling, currently it difficult to find potential markets abroad, even though there are several types of Aceh Motif Embroidery Bags are have been ordered by one of the handicraft export companies in Jakarta. In these transactions, the exporter will earn large profits rather than the producers.

\subsection{Business Problems}

\section{a. Production Aspect}

1) Increased production capacity by adding production assets such as more sophisticated machines.

2) Increased supply by increasing raw material supply.

3) Improve packing quality to attract the consumers.

4) Increase production capacity by adding business capital such as loans from banks 


\section{b. Management Aspect}

1) Increased ability of businessman to calculate the production cost in order to determine the correct selling price.

2) Improve the ability and skills of the workforce to increase the value of production.

3) Solutions providing

Regarding the main problems of business partners that have been stated, the solutions providing are as follow:

\section{a. Production Aspect}

1) Extend the production capacity and value-added products by providing more sophisticated machines.

2) Improve the marketing capacity which establishes skill to sell their own brand and packaging.

3) Looking for potential foreign markets to export embroidery bag products directly without a distributor.

4) Finding the new creations in embroidery using Typical Acehnese calligraphy as an innovation of production.

\section{b. Management Aspect}

1) Increased marketing capacity and capabilities, in terms of expanding market share and market information.

2) Improved technology in making embroidery bags to renewable technology.

3) Frequently held training for youth community as resources in order to maintain the sustainability of production and increase production of the embroidery bags.

4) Improve the promotion and introduction to consumers in various ways such as through websites, brochures, online, and others.

\section{Methodology}

These community service programs include field surveys[6][7] which useful for knowing the capacity of management/micro business organizations of the embroidery bags production. Therefore the survey conducted aims to find out how the process of making embroidery bags and knowing how to produce embroidery bags. This program[4] is carried out by using field survey methods and direct interviews with micro business owners of embroidery bags. The training method is designed using a participatory approach with reference to the andragogy learning process, through the approach:

a. Presentation of material using powerpoint presentations and simulations,

b. Discussion: individual, group,

c. Practice, and

d. Feedback from business actors is in the form of understanding the material provided. Increased production capacity is done through three stages which include:

a. Increase the supply of raw materials for making embroidery bags.

b. Expand the production assets such as production houses and buildings.

c. Increase the capital to maximizing the total production 
d. Expand marketing aspects such as adding new customers and easy access providers such as online market sales to increase sales value.

e. Training and assistance in preparing financial reports accompanied by a prepared format and Monitoring and evaluation.

\section{Result}

Community service[8-11] of embroidery bag production is held in Montasik, Aceh Besar. The research sample is a small medium-sized business of embroidery craftsmen. Regarding the activities, it was found that, in the beginning, the embroidery craftsmen producing a bag using traditional sewing machines and sewing process was still relatively not effective. This is because of the lack of capital in order to purchase the modern sewing machine. Moreover, the embroidery product is only embroidery bags. Additionally, the marketing process [3] in this business is also relatively slow, it is caused by they only focused on the buyer who directly comes to the production house. Therefore, it resulted in a lack of recognition of other buyers and in long-term this business cannot compete with the competitors[7]. The following figure describes the condition of embroidering production in Montasik.

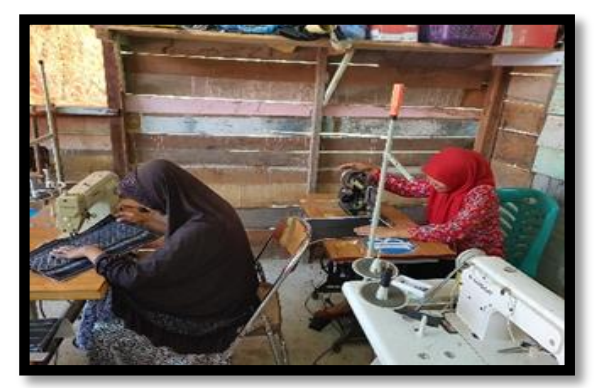

Fig. 1 Embroider Fabric Process

From the results of this community service, there are many things could be improved from the prior situation. The replacement[10] of modern sewing machines will enhance the process to be faster and resulted in good quality bags. Besides, additional product diversification which it is not only bags, but it can be in form of fabric and embroidery on the bag which brings many choices of products. This innovation will make buyers able to choose other items as well[9][8]. The following figure has described the improvement of embroidery business:

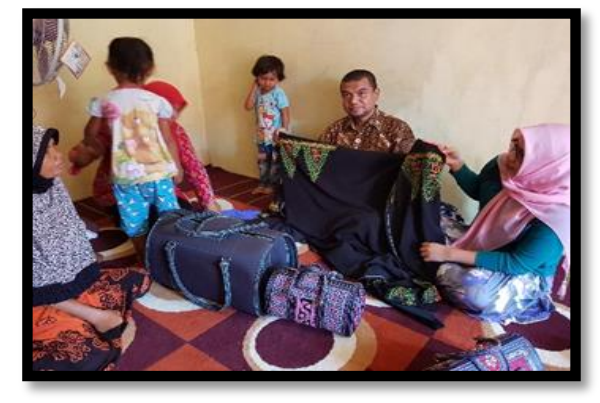


Fig. 2 Embroidery Fabric and Bags

Moreover, embroidery products necessarily realize the existence of a digital market in order to expand the market through online selling. This process is expected to promote product branding and boost the selling result. Then, increasing in the sale will be correlated to the income which ultimately adds the benefits or welfare for small and medium entrepreneurs. Some of the best-selling products from the introduction of these embroidery products online can be seen in the following figure:

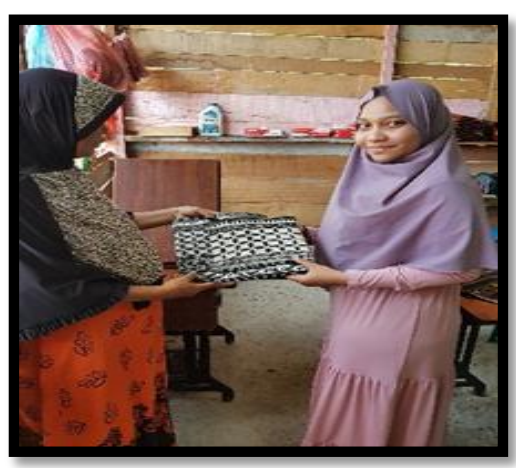

Fig. 3. Online Selling Process

However, the sales transaction in the last 2 months have been growing, before this community service is implemented, the sales of bags only ranged as much as 30 units, after the program, sales could be around 50 pieces consisting of fabrics and bags. Embroidered bags also use Acehnese embroidery, which is distinctive features. It is pointed if we use these bags, means they are from Aceh. The selling price of embroidery products is also not too expensive. It is affected to sales can be smooth and fast. Although it is small profitable, but the selling quantity is high[6]. New innovations have been developed to boost the sale.

Moreover, there are other developments which can be obtained from this program as follow:

1. Before the program, they make small-sized bags or wallet, and after the dedication, they have already bought large sized bags/wallets, such as suitcases and other large bags. Additionally, they produce sarong with the Acehnese style.

2. From this community service program, the average income has been increased, this is because of increased sales and demand of goods from consumers.

3. The process of making embroidery fabrics is also getting faster because of the addition of machines in the production of these embroidery fabrics.

4. Previously, this business only employs offline selling which is the buyer directly come to the production house, while after the community service program they apply online selling using media online. Therefore, there are so many people recognized the product and increased the demand.

\subsection{Online Marketing System}

Embroidery business, in the beginning, sells their product using offline marketing system which they are waiting for the consumers. The disadvantage of this system is the quantity of sale relatively smalls, it is caused by the consumers do not familiar with the production house. Therefore, in order to overcome this problem, our community service team tried to find a 
solution in marketing. The best solution of this problem is using marketing online system. Online marketing is done through the Kanya House shopping network. This online network has been widely known through Instagram and it takes place in Banda Aceh. Through this online network, every new embroidery product is directly marketed online. This kind of marketing system will increase the branding of the product. Additionally, the online system also uses the strategy of close friends. Finally, during the service period, embroidery business is receiving the demand of 500 embroidery bags. The bag will be used for seminars and other activities. It is a matter of pride for the partner that their products have become famous in Banda Aceh. We wish that these products can be known not only in Banda Aceh, but also throughout Indonesia.

Online marketing is also done through the online network Olx.co.id., which is famous throughout Indonesia. So, if there is a buyer from different regions interested in the embroidery of typical Acehnese calligraphy, they can make direct online purchases via online selling. Then, when there are more people known, it will increase the sell rapidly. Another obstacle when the increasing of orders is the lack of machines and work people to work on various orders. Therefore, we are as the service team helped to buy the machine in producing the Embroidery. Thus, it also additional labor can be obtained from the surrounding area. Thus, every incoming order can be completed immediately as expected. Recently, business development has increasingly progressed with the presence of large luggage products with typical Aceh embroidery. Besides, it has been developed with embroidery cloth typical of Acehnese calligraphy. This is an expansion of the product that in the future will produce products with other models and types. With the increasing number of products produced, consumers will have several choices for products and influence the number of sales.In fact, there is a lot of competition for Embroidery fabrics in Banda Aceh, especially in the Montasik sub-district. This is because in this area there is a village called Bordir. Kampung Bordir sells all types of Embroidery fabrics.

However, they can cooperate with each other in embroidery. That is, if the orders are very large, then they work together by giving part of the order to other embroidery production, it helps the Embroidery village in Montasik will grow and the societies income will rapidly increase.

\section{Conclusion}

From the community services program, it can be concluded that the community service activities have been going well which are supported by village officials, the community and all related parties. The innovation of embroidery is very beneficial for small and medium entrepreneurs because it already increases in selling quantity and enable a buyer to choose many types of embroidery product. Additionally, a new technology of embroidery machine resulted in sewing embroidery can be faster and smoother. Besides, the online marketing system has been practiced and resulted in increasing sales. This is because of the recognition of the embroidery fabric of the people out side the area. Finally, these will increase the income of small and medium entrepreneurs.

Moreover, sales of Embroidery products after this service are increasing. This is indicated by the increasing number of orders that come to the Partners production house. This is cannot be separated from the variety of products produced. Besides that, there is also the differences in the marketing system. Online marketing is very effective in order to introduce 
the product to large buyers form Aceh and Indonesia. Another result indicated that the partner's income and production have been increased significantly.

\section{References}

[1] Anggadiredja, J. Achmad, Z. Heri, P. dan Sri, I. (2008). “Processing. Self Help Spreader". Jakarta.

[2] Angipora, (2012). "Basic Marketing." Second Published. Bandung: Alumni.

[3] Assauri, N. (2009). "Marketing Management" (First Edition, Sixth Publication). PT. Kerja Grafindo Persada, Jakarta

[4] Bank Indonesia. (2013). "Acehnese Motif Embroidery Bag Industry Financing Pattern". Representative Office of Bank Indonesia: Lhokseumawe

[4] Bustami, Bastian 2007. Let's Build an Independent Business. Yogyakarta: Graha Ilmu.

[5] Kasmar. 2004. Marketing Mix Strategy. Social and Economy Programs of Fisheries. Hasanuddin University.

[6] Kotler, A. (2007). "Marketing Management, Planning Analysis, Control Implementation". Fourth Edition, erlangga: Jakarta

[7] Kotler, Philip and Gary Amstrong, (2009). "Principle of Marketing". Seventh Edition.

[8] Simamora, Bilson. (2011). "Win the Market with Effective and Profitable Marketing” PT. Gramedia Pustaka Utama, Jakarta.

[9] Silalahi, 2009. Research Method for Social Sciences. Jakarta: Refika Aditama.

[10] Sugiyono, (2016), "Research Method for Business," $9^{\text {th }}$ published. Bandung: Alfabeta.

[11] Suryana. 2008. Entrepreneurship; Practical Guidelines: Tips and Processes for Success. Jakarta: Salemba Empat. 